\title{
Cranio-vertebral transition assessment by magnetic resonance imaging in a sample of a northeast Brazilian population
}

\author{
Avaliação da transição crânio-vertebral por ressonância magnética em uma amostra da \\ população do nordeste brasileiro \\ Heitor Cabral Frade1, Caio César Nuto Leite França1, José Jailson Costa do Nascimento', \\ Maurus Marques de Almeida Holanda², Eulâmpio José da Silva Neto³, Severino Aires Araújo Neto²
}

\begin{abstract}
Platybasia and basilar invagination are important alterations of the cranial-vertebral transition. Neuroimaging-based platybasia parameters include the Welcker basal angle, distance between the apex of the odontoid and Chamberlain's line, and the clivus-canal angle. This study aimed to measure and correlate these parameters in a sample from northeast Brazil. Methods: Cross-sectional analysis of craniometric parameters from individuals submitted to magnetic resonance at an outpatient imaging center between 2011 and 2012 . Results: Of 181 analyzed cases, the Welcker basal angle averaged $128.96^{\circ}$ (SD 6.51), median distance between apex of the odontoid and Chamberlain's line was $2.27 \mathrm{~mm}$ (IQR -1.23-4.47) and the median clivus-canal angle was 150.5० (IQR 143.2-157.3). The Welcker basal angle was inversely correlated to the clivus-canal angle, and correlated to the distance between the apex of the odontoid and Chamberlain's line. Conclusion: There was a tendency to platibasia, basilar invagination and narrowing of the cranio-vertebral transition.
\end{abstract}

Keywords: platybasia; magnetic resonance imaging; cephalometry

\section{RESUMO}

Platibasia e invaginação basilar são importantes alterações da transição craniovertebral. Existem parâmetros importantes obtidos pela neuroimagem, como o ângulo basal de Welcker, distância do ápice do odontoide à linha de Chamberlain e o ângulo clivo-canal. Este estudo procurou medir e correlacioná-los em uma amostra do Nordeste Brasileiro. Métodos: Estudo transversal com medidas de indivíduos submetidos a ressonância magnética craniana em um centro de diagnóstico por imagem entre 2011 e 2012 . Resultados: Dos 181 casos analisados, o ângulo basal de Welcker teve média 128.96 (DP 6.51), a distância do ápice do odontoide à linha de Chamberlain obteve mediana $2.27 \mathrm{~mm}$ (IIQ -1.23-4.47) e o ângulo clivo-canal mediano foi $150.5^{\circ}$ (IIQ 143.2-157.3). O ângulo basal de Welcker foi inversamente correlacionado com o ângulo clivo-canal e diretamente correlacionado com a distância do ápice do odontoide à linha de Chamberlain. Conclusão: Houve uma tendência a platibasia, invaginação basilar e estreitamento da transição craniovertebral, que poderiam ser influenciados pela natureza multirracial e por fatores antropológicos da população estudada.

Palavras-chave: platibasia; imagem por ressonância magnética; circunferência craniana.

The cranio-vertebral transition (CVT) is composed by the base of the occipital bone and the first two cervical vertebrae, atlas and axis ( $\mathrm{C} 1$ and $\mathrm{C} 2$, respectively). This region is susceptible to conformational abnormalities, such as platybasia flattening of skull base - and basilar invagination - protrusion of the tooth of the $\mathrm{C} 2$ to the posterior fossa. They are mutually associated, and both may also relate to cerebellar tonsil herniation. Clinical repercussions are varied and derive from compression of nervous structures or obstruction of cerebrospinal fluid circulation, with consequent hydrocephalus and syringomyelia ${ }^{1}$.

Imaging exams are indispensable in the assessment of CVT, and the gold-standard is magnetic resonance imaging (MRI), especially because it can demonstrate both musculoskeletal and nervous elements involved. Craniometric imaging parameters were first established last century, notably from German

1 Universidade Federal da Paraíba, João Pessoa PB, Brasil;

Universidade Federal da Paraíba, Departamento de Medicina Interna, João Pessoa PB, Brasil;

${ }^{3}$ Universidade Federal da Paraíba, Departamento de Morfologia, João Pessoa PB, Brasil;

Correspondence: Severino Aires Araújo Neto; Departamento de Medicina Interna da UFPB; Cidade Universitária, s/n; $58051-900$ João Pessoa PB, Brasil;

E-mail: severinoaires@hotmail.com

Conflict of interest: There is no conflict of interest to declare.

Received 26 July 2016; Received in final form 28 February 2017; Accepted 14 March 2017. 
radiograph-based studies, but some are still used for evaluating CVT by computerized tomography (CT) or MR $\mathrm{MR}^{1}$.

Chamberlain's line extends from the posterior portion of the hard palate up to the posterior margin of the foramen magnum (ostium). The distance between the apex of the odontoid and the Chamberlain's line (DOCL) is used to measure the projection of the axis into the posterior fossa to diagnose basilar invagination.

The Welcker basal angle (WBA) and the clivus-canal angle (CCA) are also largely used for evaluation of platybasia ${ }^{1}$.The WBA measures angulation of the skull base and is obtained by two lines: one traced from the nasion up to the tubercle of sella turcica and another line from the latter to the anterior margin of the foramen magnum (basion). Values above a normal limit of $140^{\circ}$ have been considered diagnostic of platybasia ${ }^{1,2}$. The CCA is measured between the line that follows parallel to the clivus and another that borders the posterior surface of the odontoid process $^{2}$. Values lower than $150^{\circ}$ are considered abnormal ${ }^{1}$. A narrower angle increases the risk nervous compression.

For several decades, researchers have reported a high prevalence of platybasia and basilar invagination in the northeastern Brazil population when compared with other regions within and beyond Brazilian borders ${ }^{3,4}$. Studies conducted in northeast Brazil by Silva et al. ${ }^{3,4}$, and Alves et al. ${ }^{6}$, have also found an association with brachycephaly ${ }^{3,4,6,7}$ - a condition in which the lateral diameter of the skull is disproportionately large. In a corpse-based study, also conducted in northeastern Brazil, there was a surprisingly high rate of brachycephaly (77.6\%), higher than that reported in other populations associated with brachycephaly ${ }^{8}$. This condition is also popularly referred to as "cabeça-chata" (flat head), a term often used in a pejorative manner to define the northeastern population'.

Brachycephaly and its association with platybasia may not be pathological, but rather a phenotypic tendency of a population, apparently related to ethnic-anthropological factors in northeast Brazil ${ }^{10}$. Thus, diagnosing platybasia and basilar invagination with craniometric parameters derived from overseas samples may not be appropriate. However, there have not previously been imaging studies assessing CVT parameters in the northeastern population.

The authors aimed to assess craniometry in a sample from the northeastern Brazil population via MR imaging. Specific objectives were: 1) outline a profile of the sample for the DOCL, WBA and CCA measures; 2) verify if there were correlations between these three parameters.

\section{METHODS}

Data was obtained from head MRIexaminations, conducted at an imaging service at outpatient level in "Sertão" (drylands) of the state of Paraíba (NE). The MR imaging was carried out by spontaneous demand on that service between January 2011 and December 2012. All patients aged 18 years or above were included. Exclusion criteria were: manifested clinical suspicion of CVT disease by the referring physician, surgery to the base of the skull or important previous cranio-vertebral trauma, technical difficulties in the identification of the parameter structures, resulting from positioning errors, misangulation and imaging artifacts, such as those generated by metallic material or patient movement. If a patient had more than one examination during the period of the study, only the first one was included.

All examinations were carried out in an open device, of 0.35 T (Magnetom C!, Siemens Medical Solutions, Erlangen, Germany, 2011). The parameters were outlined in the mid sagittal plane of T1 3D sequence (magnetization-prepared rapid gradient-echo or MP-RAGE) acquired at the sagital plane, with thickness varying from 0.9 to $1.1 \mathrm{~mm}$. Images were analyzed in digital DICOM format, by means of an open version of the visualization software Osirix in its free version 3.9.2 (Mac-Apple platform).

The DOCL, CCA and WBA were measured according to the techniques described by Smoker ${ }^{1}$ and Amaral et al. ${ }^{2}$ (Figures 1, 2 and 3).

The data was analyzed by means of the statistical software R3.2.0. The Shapiro-Wilk test was used to assess normality. The comparison between genders was made using the unpaired Wilcoxon's test. Spearman's correlation was used to verify the relation between the variables, with the p-value corrected by Holm's method. The value of $\mathrm{p}<0.05$ was considered as statistically significant.

The study was substantiated on secondary data (tests), guaranteeing privacy and confidentiality of the patients, ensuring the non-use of the information to the detriment of the people, according to Resolution 466/12 of the National Council of Health. The project was approved by

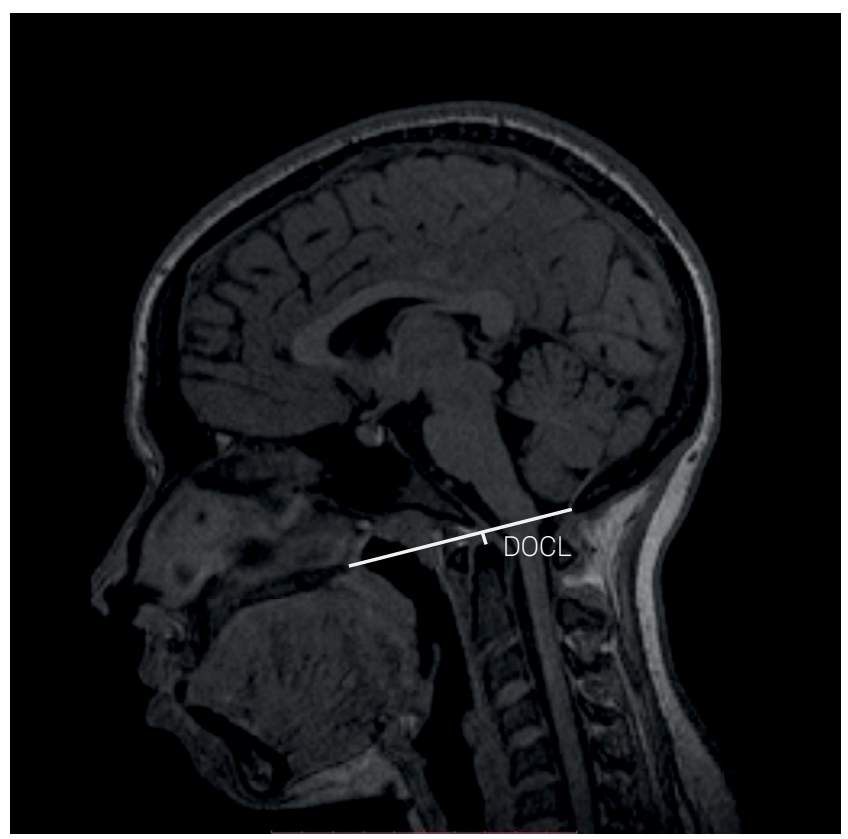

Figure 1. Distance between the odontoid apex and Chamberlain's line (DOCL). 


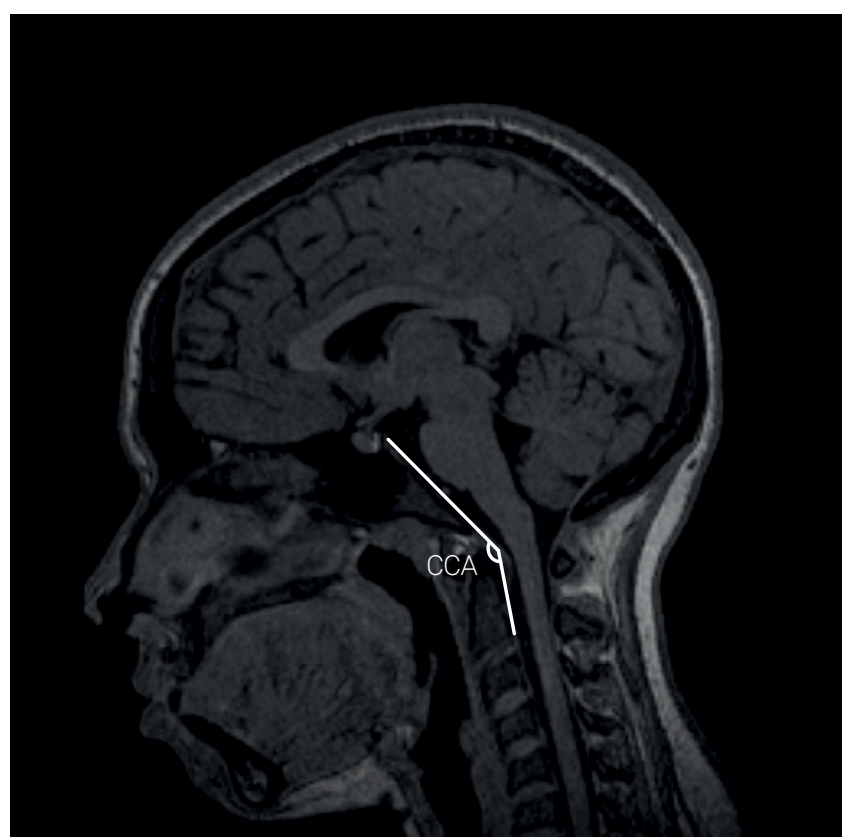

Figure 2. Clivus-canal angle (CCA).

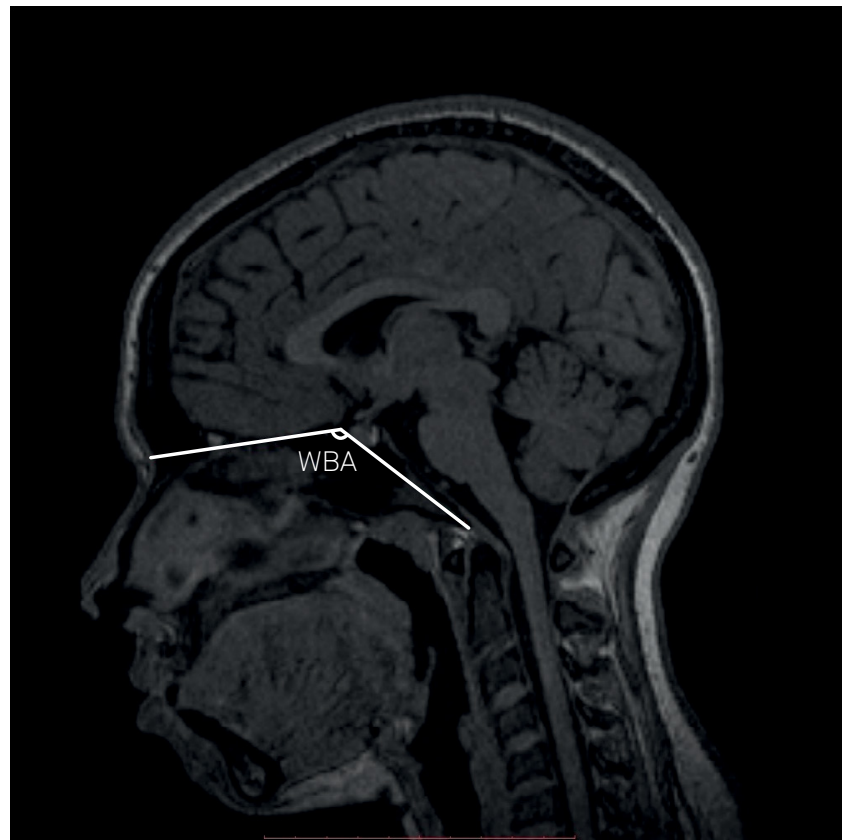

Figure 3. Welcker basal angle (WBA).

Table. Craniometric parameters.

\begin{tabular}{lccccccc}
\hline \multirow{6}{*}{ Craniometry } & \multicolumn{5}{c}{ Percentiles } & Mean \\
\cline { 2 - 6 } & 2.50 & 25 & 50 & 75 & 97.50 & $(\mathrm{SD})$ \\
\hline WBA $\left(^{\circ}\right)$ & 117.1 & 124.3 & 128.5 & 133.4 & 142.65 & $\begin{array}{c}128.96 \\
(6.51)\end{array}$ \\
\hline DOCL $(\mathrm{mm})$ & -7.55 & 1.23 & 2.27 & 4.47 & 15.5 & $\begin{array}{c}2.25 \\
(5.06)\end{array}$ \\
\hline CCA $\left(^{\circ}\right)$ & 121.7 & 143.2 & 150.5 & 157.3 & 172.5 & $\begin{array}{c}150.14 \\
(11.37)\end{array}$ \\
\hline
\end{tabular}

WBA: Welcker basal angle; DOCL: distance between odontoid and Chamberlain's line; CCA: clivus-canal angle; SD: standard deviation. the Ethics in Research Committee of the institution (CAAE: 30255914.1.0000.5188), with substantiated exemption of the consent term. The use of the images was authorized by the direction of the service. There was no interference in the protocol of the examinations or any clinical or surgical intervention in function solely for this research.

\section{RESULTS}

A total of 181 head MRIs were studied. Eighty participants (44.2\%) were men and 101 (55.8\%) were women. The median age was 46 years $(\mathrm{IQR}=32-63)$. The craniometric variables are described in Table.

There was no significant difference in craniometric parameters for gender and age.

The WBA showed a parametric distribution, with an average of $128.96^{\circ}$ (confidence interval of 95\%, 128.01-129.91).

There was no significant correlation between the CCA and DOCL ( $p=-0.215 ; p=0.26)$, but there was a positive correlation between the WBA and the DOCL $(p=0.366$; $<<0.0001)$, as well as an inverse correlation between the WBA and the CCA $(p=-0.415 ; p<0.0001)$ (Figures 4, 5 and 6).

\section{DISCUSSION}

The use of lines, distances and angles that relate to anatomical landmarks of a CVT helps in the diagnosis of alterations such as platybasia and basilar invagination ${ }^{2,11}$. Despite most of these measures having been designed when radiographs were the only imaging method available $e^{1,12,13,14}$, they are currently adopted for CT and MR imaging analysis.

There has been considerable variation in craniometric parameters across studies. The WBA has varied broadly, with one reported average of $115.41^{\circ}\left( \pm 8.45^{\circ}\right)$ for Netto et al. ${ }^{7}$.

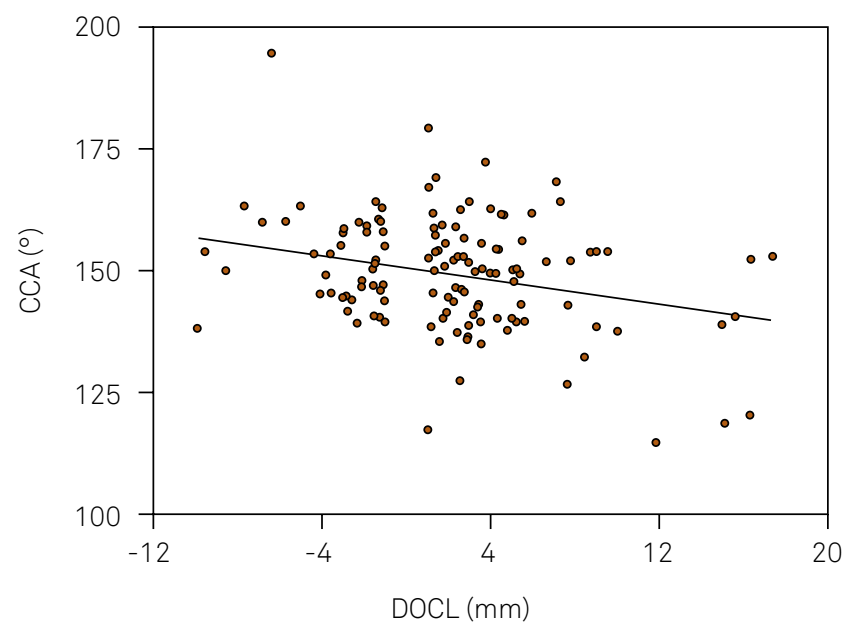

Figure 4. Relationship between clivus-canal angle (CCA) and distance between odontoid apex and Chamberlain's line (DOCL). 


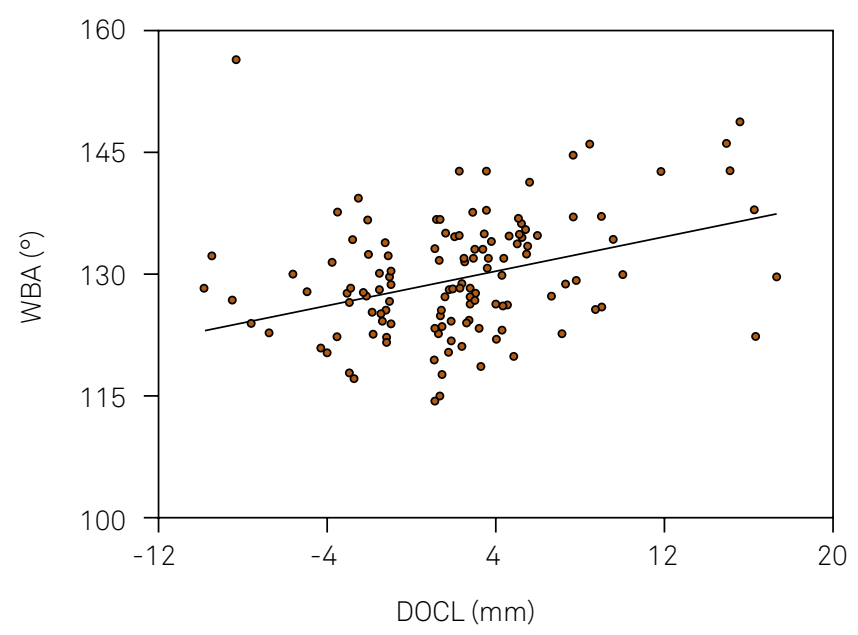

Figure 5. Relationship between Welcker basal angle (WBA) and distance between odontoid apex and Chamberlain's line (DOCL).

Other authors have reported relatively large amplitudes: $103.5^{\circ}$ to $131.5^{\circ}$ for Boogard ${ }^{15} ; 115^{\circ}$ a $140^{\circ}$ for List $^{16} ; 115^{\circ}$ to $150^{\circ}$ for Walsh et al. ${ }^{17} ; 120^{\circ}$ to $147^{\circ}$ for McGreger ${ }^{14} ; 121.5^{\circ}$ to $148.5^{\circ}$ for Brailsford ${ }^{13}$; $115^{\circ}$ to $140^{\circ}$ Royo-Salvador ${ }^{18}$; and $97^{\circ}$ to $133.2^{\circ}$ for Batista et al..$^{19}$

There is still no consensus over the upper limit for DOCL values, which range from 2.0 to $6.6 \mathrm{~mm}^{1,20,21}$. This difference is not insignificant when compared to the small dimensions of CVT and hence could lead to considerable changes in specificity in the diagnosis of basilar invagination, as well as in the estimated prevalence ${ }^{11,22}$.

Taking into consideration the DOCL upper limit of $2 \mathrm{~mm}^{20}$, more than half of the participants in this study would be diagnosed with basilar invagination, which would be unlikely for individuals who come to imaging services by spontaneous demand.

According to Smoker, a CCA value lower than $150^{\circ}$ is considered abnormal ${ }^{1}$. Botelho and Ferreira ${ }^{11}$ analyzed the CCA via MRI, obtaining an average of $148^{\circ} \pm 9.8^{\circ}$ (with a range from $129^{\circ}$ to $179^{\circ}$ ). Batista et al. ${ }^{19}$, analyzing with the use of $\mathrm{CT}$, obtained an average of $153.6^{\circ} \pm 7.6^{\circ}$ (varying from $132.3^{\circ}$ to $173.9^{\circ}$ ).

Our study showed a CCA with an average of $150.14^{\circ} \pm 11.37^{\circ}$ - very close to the values cited by Botelho and Ferreira ${ }^{11}$ and Batista et al. ${ }^{19}$, which is apparently higher than that suggested by Smoker ${ }^{1}$. Despite Smoker ${ }^{1}$ having demonstrated significant correlation between the CCA and DOCL, none was found in this study. Thus, it can be speculated that the values of the CCA obtained by MRI or CT of asymptomatic patients seem to be higher than the ones published using radiographs, from which normality standards were defined ${ }^{1,19}$; or, alternatively, it is possible that each population naturally presents with different values.

Northeastern Brazilian population tendency toward brachycephaly as well as other CVT peculiarities have been addressed in previous clinical ${ }^{4,5,23}$, and anthropological studies 9 . A strong relationship between brachycephalia and

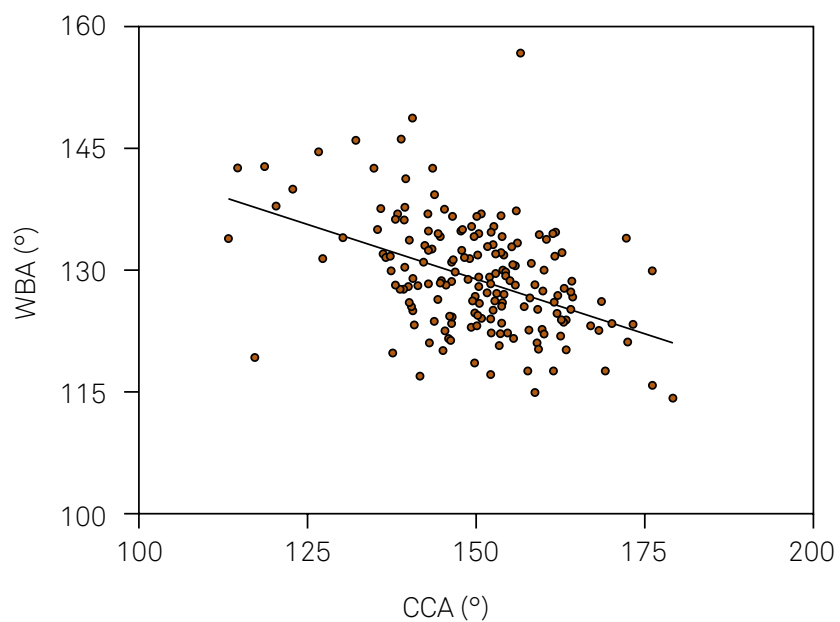

Figure 6. Relationship between Welcker basal angle (WBA) and clivus-canal angle (CCA).

alterations of the CVT in patients submitted to surgeries in this region was also found by other researchers ${ }^{4,5}$.

Nonetheless, some of the variance between samples may be also attributed to different imaging methods used in each study, as well as to a lack of validation and standardization of the old craniometric techniques as they are adapted to new imaging resources, such as $\mathrm{CT}$ and MRI.

In this study, an inverse correlation between the WBA and CCA suggests that flattening of the skull base may accentuate thebulbo-pontine transition in its passage in the CVT. A similar correlation was referred to by Joaquim et al..$^{22}$, who demonstrated that the presence of platybasia and a decreased clivus seem to favor a protrusion of the cervical spine to the inside of the skull base (basilar invagination) ${ }^{24}$. Previous studies have already hypothesized that the presence of platybasia may be associated with compression of posterior fossa structures by mechanical opposition to the apex of the odontoid process ${ }^{1,4,5}$.

CVT imaging analysis is still poorly-described in the northeastern population, especially those from the countryside. Despite all participants included in this studywere chosen from a single reference imaging center in the countryside of the state of Paraíba, their place of birth was not verified.Thus, it is not possible to know how much of the sample was indeed born in that region and how accurately this sample represents Paraíba or Brazilian Northeast populations as a whole. Therefore, this study could provide further evidence to help define northeastern craniometric standards and its peculiarities.

In conclusion, the inverse relation of the WBA and the CCA, demonstrated here, suggests that platybasia, despite not being directly involved in nervous compressions, may be a factor associated with this, as it can contribute to the narrowing of the passage of the neuroaxis in the CVT. The correlation found between the WBA and DOCL demonstrates the relationship between platibasya and basilar invagination, already referred to in literature, and reinforces the clinical importance of platybasia. 
Descriptive results of all three parameters also suggest that their normal ranges may be different from those previously shown in international studies, which demands further research involving larger sampling of normal individuals, not only to confirm a difference, but also to propose new appropriate limits for people from Northeast region.

\section{References}

1. Smoker WR. Craniovertebral junction: normal anatomy, craniometry, and congenital anomalies. Radiographics. 1994;14(2):255-77. https://doi.org/10.1148/radiographics.14.2.8190952

2. Amaral DT, Amaral LL, Filho GH, Puertas E. Craniovertebral junction: normal anatomy and craniometry. Coluna/Columna. 2004;3(2):100-3.

3. Silva AB, Moraes AA, Bessa IC, Sesana WE. [Cerebello-pontine angle syndrome associated with cranio-vertebral malformation: report of two cases]. Arq Neuropsiquiatr. 1972 ;30(1):84-7. Portuguese. https://doi.org/10.1590/S0004-282X1972000100009

4. Silva JA, Brito JC, Nóbrega PV, Costa MD, Souza AB. Achados cirúrgicos em 260 casos de impressão basilar. Arq Neuropsiquiatr. 1994;52(3):363-9.

5. Silva JA, Holanda MM. Basilar impression, Chiari malformation and syringomyelia: a retrospective study of 53 surgically treated patients. Arq Neuropsiquiatr. 2003;61(2B):368-75 https://doi.org/10.1590/S0004-282X2003000300009

6. Alves HA, Santos MI, Melo FC, Ribeiro W. Comparative study of the cephalic index of the population from the regions of north and south of Brazil. Int J Morphol. 2011;29(4):1370-4. https://doi.org/10.4067/S0717-95022011000400050

7. Netto DS, Nascimento SR, Ruiz CR. Metric analysis of basal sphenoid angle in adult human skulls. Einstein (Sao Paulo). 2014;12(3):314-7. https://doi.org/10.1590/S1679-45082014A02933

8. Nascimento JJ, Macêdo AE, Ribeiro EC, Souza NA, Silva Neto E. Estimativa do sexo e mensuração de índices cranianos do acervo pertencente ao departamento de morfologia da UFPB. In: Anais do $26^{\circ}$ Congresso Brasileiro de Anatomia, $2^{\circ}$ Encontro de Ligas Estudantis de Morfologia; 29 set-2 out 2014; Curitia, PR. São Paulo: Sociedade Brasileira de Anatomia; 2014. p. 781.

9. Queiroz AC. Politicamente correto e direitos humanos. Brasília: SEDH; 2004.

10. Carvalho OA. Análise das anormalidades de desenvolvimento na população pré-história do Sítio Furna do Estrago, Pernambuco. Rio de Janeiro: Escola Nacional de Saúde Pública 1995.

11. Botelho RV, Ferreira ED. Angular craniometry in craniocervical junction malformation. Neurosurg Rev. 2013;36(4):603-10. https://doi.org/10.1007/s10143-013-0471-0

12. Chamberlain WE. Basilar impression (platybasia): a bizarre developmental anomaly of the occipital bone and upper cervical spine with striking and misleading neurologic manifestations. Yale $J$ Biol Med. 1939;11(5):487-96.
13. Brailsford JF. The radiology of bones and joints. Am J Med Sci. 1936;192(2):281.

14. McGregor M. The significance of certain measurements of the skull in the diagnosis of basilar impression. Br J Radiol. 1948;21(244):171-81. https://doi.org/10.1259/0007-1285-21-244-171

15. Boogard JA. Basilar impression: its causes and consequences. Nederl Tysdschr v Geneesk Tweede, Afedling. 1865;1:81-108.

16. List CF. Neurologic syndromes accompanying developmental anomalies of occipital bone, atlas and axis. Arch Neurol Psychiatry. 1941;45(4):577-616. https://doi.org/10.1001/archneurpsyc.1941.02280160009001

17. Walsh MN, Camp JD, Craig WM. Basilar invagination of the skull (so-called platybasia): report of a case with operation. Mayo Clin Proc. 1941:449-52.

18. Royo-Salvador MB. [Platybasia, basilar groove, odontoid process and kinking of the brainstem: a common etiology with idiopathic syringomyelia, scoliosis and Chiari malformations]. Rev Neurol. 1996;24(134):1241-50. Spanish.

19. Batista UC, Joaquim AF, Fernandes YB, Mathias RN, Ghizoni E, Tedeschi H. Computed tomography evaluation of the normal craniocervical junction craniometry in 100 asymptomatic patients. Neurosurg Focus. 2015;38(4):E5. https://doi.org/10.3171/2015.1.FOCUS14642

20. Goel A. Basilar invagination, Chiari malformation, syringomyelia: a review. Neurol India. 2009;57(3):235-46. https://doi.org/10.4103/0028-3886.53260

21. Smith JS, Shaffrey Cl, Abel MF, Menezes AH. Basilar invagination. Neurosurgery. 2010;66(3 Suppl):39-47. https://doi.org/10.1227/01.NEU.0000365770.10690.6F

22. Joaquim AF, Fernandes YB, Mathias RN, Batista UC, Ghizoni E, Tedeschi $\mathrm{H}$ et al. Incidence of basilar invagination in patients with tonsillar herniation? A case control craniometrical study. Arq Neuropsiquiatr. 2014;72(9):706-11. https://doi.org/10.1590/0004-282X20140113

23. Silva JAG. Impressão Basilar. In: Silva JAG. Malformações occipitocervicais: impressão basilar, malformação de Chiari, siringomielia, platibasia. Recife: Ed Universitária; 2003. p. 169-300.

24. Pang D, Thompson DN. Embryology and bony malformations of the craniovertebral junction. Childs Nerv Syst. 2011;27(4):523-64. https://doi.org/10.1007/s00381-010-1358-9 